\title{
TRANSPORT AND ENVIRONMENTAL SUSTAINABILITY INFRASTRUCTURE IN THE AMAZON: THE RECONSTRUCTION OF HIGHWAY BR-319 AND ITS CONSEQUENCES IN REGIONAL CONTEXT
}

\author{
INFRAESTRUTURA DETRANSPORTE E \\ SUSTENTABILIDADE AMBIENTAL NA AMAZÔNIA: A \\ RECONSTRUÇÃO DA RODOVIA BR-319 E SUAS \\ CONSEQUÊNCIAS NO CONTEXTO REGIONAL
}

\author{
Rafael Vieira da Silva \\ Programa de Engenharia Ambiental/UFRJ \\ Assed Naked Haddad \\ Programa de Engenharia Ambiental/UFRJ \\ Corbiniano Silva \\ Departamento de Geologia/UERJ
}

\begin{abstract}
The need for restoration of Brazilian highways make up a strong proposal for economic development in the country has supported currently considering the gradual reduction of economic waste in implementation of reconstruction activities, restoration and restructuring of roads and / or highways, and the reducing environmental impacts in the vicinity of these projects, especially the areas of environmental/ecological relevance. In this perspective, the restructuring of the BR-319 highway from Manaus - Amazonas state - to Porto Velho, in Rondonia, from technical and environmental aspects, a set of actions were structured and entered as key variables in the reconstruction process road network of the country, established by law no.10.233 (05.06.2001), which states in its general principles that transport infrastructure management must reconcile transport with environmental preservation. In this context, the use of mechanisms and practices associated with the theme environment and have the ability to gradually reduce potential environmental impacts from the highway restoration activities are part of a sustainable development project of the Brazilian state, assuming the use of methods and validated techniques in environmental engineering and considering the process of mitigating environmental impacts. So, to discuss the restructuring of the BR-319 highway, which calls for a paradigm doubtful about the road network to be installed in the Amazon region, especially given the prospect of environmental impacts, we emphasize the challenge for the implementation of technical environmentally sustainable, in order to reduce environmental Criticality inherent in the restructuring of this development process.
\end{abstract}

Keywords: Deforestation, Environmental Management of Highways, BR-319, Amazon

Biome. 


\section{RESUMO}

A necessidade de restauração das rodovias brasileiras compõe uma forte proposta de desenvolvimento econômico em que o país tem se apoiado atualmente, considerando a diminuição gradual de desperdício econômico na execução de atividades de reconstrução, restauração e reestruturação de estradas e/ou rodovias, bem como a redução dos impactos ambientais no entorno desses empreendimentos, sobretudo as áreas de relevância ambiental/ecológica. Nesta perspectiva, a reestruturação da rodovia BR-319, desde Manaus - no estado do Amazonas - até Porto Velho, em Rondônia, a partir de aspectos técnicos e ambientais, um conjunto de ações foram estruturadas e inseridas como variáveis principais no processo de reconstrução da malha rodoviária do país, estabelecidas pela lei no-10.233 (05/06/2001), a qual determina em seus princípios gerais que o gerenciamento de infraestrutura de transporte deve compatibilizar os transportes com a preservação do meio ambiente. Neste contexto, o uso de mecanismo e práticas associadas ao tema meio ambiente e que apresentam a capacidade de reduzir gradualmente os potencias impactos ambientais oriundos de atividades de restauração de rodovias integram um projeto de desenvolvimento sustentável do Estado brasileiro, admitindo-se o uso de métodos e técnicas validadas no âmbito da engenharia ambiental e considerando o processo de mitigação dos impactos ambientais. De tal modo, ao discorrer sobre a reestruturação da rodovia BR-319, a qual conclama um duvidoso paradigma sobre a malha viária a ser instalada na região amazônica, sobretudo em razão da perspectiva de impactos ambientais decorrentes, enfatizamos o desafio para a implantação de técnicas ambientalmente sustentáveis, com o propósito de redução das criticidades ambientais inerentes ao processo de reestruturação deste empreendimento.

Palavras-Chave: Desmatamento, Gestão Ambiental de Rodovias, BR-319, Bioma Amazônia.

\section{INTRODUCTION}

The discussion on deforestation in the Brazilian Amazon has been the subject of forums and conferences in recent decades, whose developments unfortunately turned into actions to point absolute guidelines to reduce it, especially with the understanding that deforestation in the region is associated to environmental issues and provides environmental impacts technically worrying scales.

Understanding, unequivocally, that investment in road infrastructure actions directly and indirectly affect the socio-economic activities and especially environmental, both local and regional, it is important imperative of monitoring and control for the Amazon biome. Thus, given that redraws the road network as what has been defined under the Brazilian Agenda 21, it is understood that it will consist of alignment between public transport policy and sustainable development. However, it is up to national legal obedience displayed by the program of environmental regularization of federal highways - Federal Highway 
Program Environmentally Sustainable (PROFAS) - which provides the adequacy of federal paved road network, making this underlying environmental standards that harmonize the need for their conservation, restoration and permanent improvement in order to achieve lower environmental debts. So, in that the rate of deforestation has variations, joint mobilizations of the Government and civil society have resulted in proposals, including the "zero deforestation" (Young, 2007), as well as the establishment of reduction targets deforestation that since 2008, part of the National Climate Change Plan in.

The BR-319 highway brings in its recent history a set of technical and scientific questions that suggest mitigation practices, using methods and techniques validated in environmental engineering, aiming for process control and monitoring from practices and technologies environmentally sustainable. In this sense, assuming that the Transport and Environment regarding particular characteristics of the generated impacts, especially in the case of the Amazon region, the search for identifying the BR-319 highway promoted in its reconstruction process, including reducing local deforestation with the use of avoided deforestation mechanism, especially through the implemented environmental programs, is also admit that this mechanism has technical functionality, according to what was proposed by the State in the implementation of public policies in transport relation - environment.

So, this article aims to identify the potential for avoided deforestation, applied as a sustainability mechanism, depending on the BR-319 highway restructuring in the Amazon biome.

\section{GENERAL ASPECTS OF THE AMAZON BIOME}

According to IBGE (2015), the Amazon, established in Article 2 of Law No. 5,173, of October 1966, covering the Brazilian states Acre, Amapá, Amazonas, Mato Grosso, Pará, Rondônia, Roraima, Tocantins, Maranhão and part of five municipalities of Goiás. It represents $59 \%$ of the Brazilian territory, spread over 775 municipalities, where they lived in 2000, according to the Census, 20.3 million people (12.32\% of the population), of which $68.9 \%$ that quota in urban areas. 
In the view of Queiroz (2008), "... the exploitation of its potential and its conservation are adversely affected due to its large size, diversity of habitats and rich biodiversity. Thus, gaps are left open with regard to its maintenance, monitoring and sustainable use, which facilitates the action to deforestation."

In Brazil, the Amazon (Legal) in principle reproduce the situation described above. In this region sets up a peculiar situation in which the population of the states that comprise it maintains very high levels of poverty and quality of life very low compared to the national average, a situation characterized by a temporal stability that does not reflect the several transformations in which is undergoing the region's economy over the past three decades. It exists in the region a process of growth, arising from the exploitation of the abundance of its natural resources, amid chronic poverty and in absentia of several attempts generally directed by the state to promote local development.

In the Population Census 2000 (IBGE, 2010) the population of the macroregion of the Amazon (which houses the biome) had a population density of just over 3 inhabitants $/ \mathrm{km}^{2}$. Over $50 \%$ of this population in its unnatural most of the region, are located in urban centers. The economically active population was 8.5 million, equivalent to $42 \%$ of the total population. GDP growth has been double the country and in 2005 represented $7.9 \%$ of national GDP. The GDP per capita of $R \$ 7,886.00$ in 2005 accounted for about 2/3 of GDP per capita average Brazilian, whose value reached US $\$ 11,658.5$.

The recognition that the "urban challenge" in the Brazilian Amazon region reveals an occupation model that results in a process of deforestation of the Amazon, with developments that have high complexity, since the environmental context in which it is entered this biome is characterized the loss of land along the roads (the right of way / easement area); by land speculation these lands; the growth of cities; by increasing the large-scale livestock industry; by logging and also on family farms, currently in the mechanization process.

Assuming the course of the discussion a conductor concept, will give emphasis to the biome term as a set of life (plant and animal) constituted by grouping types of contiguous and identifiable vegetation on a regional scale, with similar geo-climatic conditions and shared history of changes, resulting in a very biological diversity, as defined by the IBGE - Brazilian Institute of Geography and Statistics (2004). 
Within this concept and in the context of its area of influence, the Brazilian biomes present spatial participation in the national territory so that the unfolding discussion on the environmental and economic context permeate interpretative analysis from the defined geographical scope, as shown in table 1.

Tabela 1. Continental Brazilian Biomes.

\begin{tabular}{l|c|c}
\hline \hline Continental Brazilian Biomes & Approximate Area $\left.\mathbf{( k m}^{\mathbf{2}}\right)$ & Percentage \\
\hline \hline Amazônia & 4.196 .943 & $49,29 \%$ \\
\hline Cerrado & 2.036 .448 & $23,92 \%$ \\
\hline Mata Atlântica & 1.110 .182 & $13,04 \%$ \\
\hline Caatinga & 844.453 & $9,92 \%$ \\
\hline Pampa & 176.496 & $2,07 \%$ \\
\hline Pantanal & 150.355 & $1,76 \%$ \\
\hline Total Area Brazil & $\mathbf{8 . 5 1 4 . 8 7 7}$ & $100 \%$ \\
\hline \hline
\end{tabular}

A significant share in the percentage contribution to the Amazon biome determines how mighty is its size, making exponential biodiversity issues of environmental public policy actions, the challenges of urbanization and, above all, logistics and ground infrastructure for the inclusion of any modes of transportation.

There is no doubt that, given the qualitative and quantitative information about the Legal Amazon regarding their conservation status, the environmental and economic contexts are intertwined and are the socio-economic and environmental reality that surrounds the Amazon region and its population. Thus, it is assumed that the rate of deforestation, while the object of analysis of evolution or involution of the environmental and economic aspects, have shown high records, surpassing historical data, as noted Fearnside (2009).

The production capacity associated with the traditional model of occupation of the Amazon allows to understand the existence of dualities, influenced by the current state of the Brazilian economy, featuring the advancing frontier in the macro-region of the Amazon and its reciprocity in the deforestation rate. However, there is this direct relationship associative bias presented by students of this subject, establishing the mismatch of the evolution of the economy with the expansion of deforestation. 
It should be noted that deforestation within the contexts in evidence (environmental and economic), is influenced by the dynamics of the export market, driven mainly by logging activities and agribusiness.

Among the states that in the last decade and even today participate in expressive mode of the deforestation process in the region, include:

- Pará (in the southern region of the state);

- Mato Grosso (in its northern part);

- Amazonas (the southern part);

- Maranhão (in the southeastern state);

- Rondônia; and

- Southeastern portion of Acre.

This distribution can be translated, or the reason for their existence can be identified by the nature commodification process that, in view of Becker (2005), treats the Amazon regional dynamics as a target structural and cyclical changes, analyzing from until the settlement calls "urban forest" implemented in these states and which have a more effective participation in deforestation in the light of economic and environmental context.

Within this perspective and considering that addressed Becker (2005), "The problem is that all actors in the Amazon (ranchers, loggers, Indians, small producers) want as the first demand, the state's presence, for different reasons. As a second demand wish zoning. Such demands express on the one hand, the need to clearly define the rules of the game, ie, institutional strengthening, and, second, the relevance of sub-regionalization, because the regions have their own purposes and specific problems. The state can best engage with these specific needs, find the necessary partnerships and better target resources to better serve them." So, what is relevant, also argued that the Becker (2005), is the fact that the destruction by deforestation or any other forms that denote damage to the natural capital of the Amazon biome determine the reduction of this loss, especially when capacity to value (measure economic value) the forest is able to compete with the extracted product to market values, ie, wood and other goods.

Anyway, given the condition that the state is endowed with a power as authority to redefine environmental public policy actions for the socio- 
environmental context of the change in the Brazilian Amazon region. Such condition will enhance the promotion of correlations between environment and economy capable of consolidating a "new order" technological-social and environmental for the urban restructuring, the recognition of communities, the implementation of terrestrial infrastructure, as well as alternative and renewable energy, with the trend and the preservationist and conservationist purpose of the Brazilian Legal Amazon's resources and its biodiversity.

\section{THE PROBLEM OF DEFORESTATION IN THE AMAZON REGION}

To which argues Moreira et al. (2009), "In the Brazilian Amazon about $90 \%$ of deforestation has occurred within a buffer of $100 \mathrm{~km}$ along roads built by the federal government (Ahmed et al, 2002). The transport infrastructure extension within tropical borders, especially roads, encourages immigration, increases farm and economic development. As a result, the vegetation is transformed into human artifacts for urban and agricultural use of the land, (Arima, 2005). The environmental impacts of roads are of particular concern in regions where infrastructure networks are expanding rapidly in high ecological value areas in the Amazon Basin (Schelhas and Greenberg, 1996); Reid and Bowles (1997), and Arima (2005)."

In this context, performed a quantitative observation, ie, a comparative analysis of the decade course of 2000 , on the evolution of deforestation, obtained technical result is that there was a relative fall in deforestation (Figure 1), as environmental degradation element without identifying the triggering event. However, the same setback does not show the maintenance of the sustainability of bases in the region and/or in the Amazon biome. 
Graph 1. Evolution of deforestation: Relative variation in the period 2000-2008.

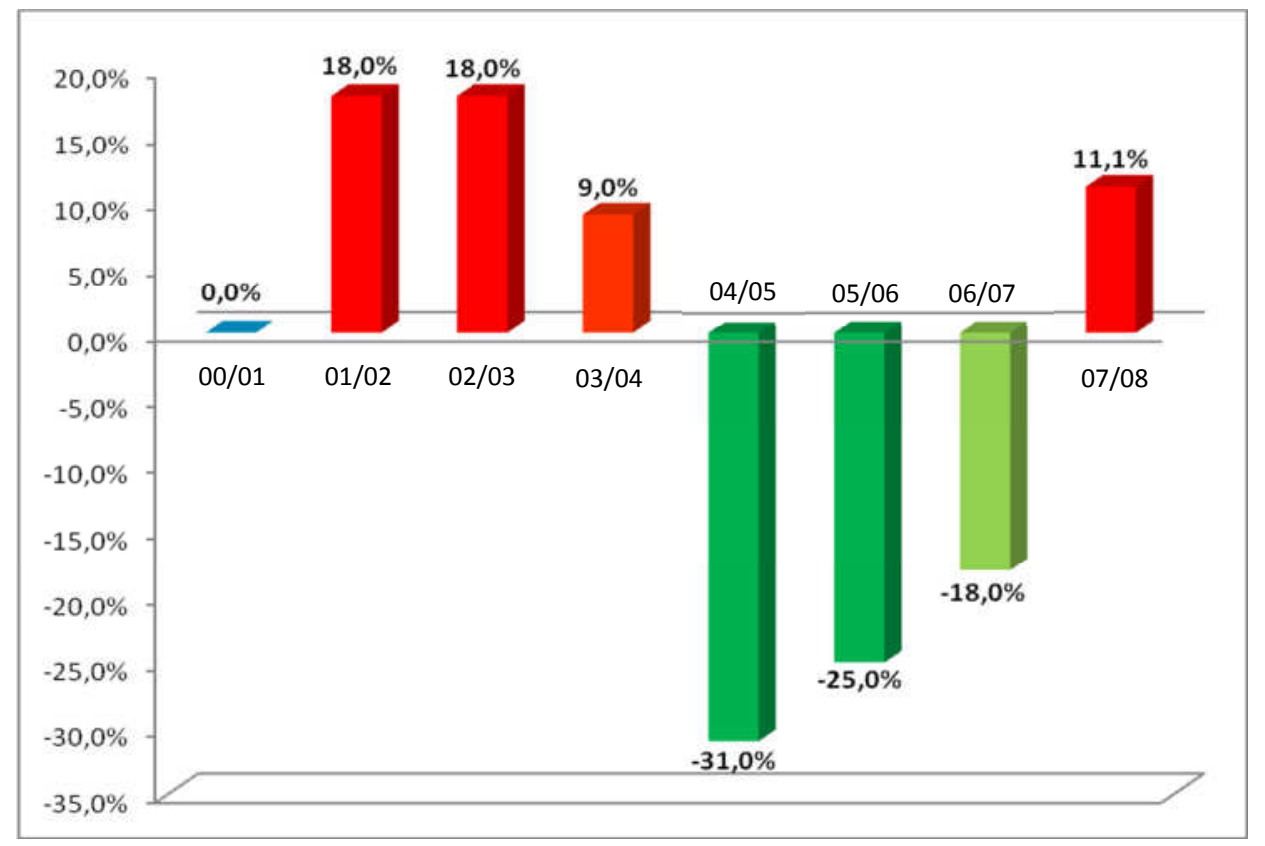

Therefore, Margulis $(2004)^{1}$ said that deforestation is associated with deploying large-scale agricultural projects. In turn, Prates (2008) argued that deforestation has several factors, being spatially uneven. ${ }^{2}$.

Based on the analytical principle "point and counterpoint" it is understood that the deforestation dynamics and has had its aggravation from derivatives settlements of the urbanization process also reflected by the rural population.

In perspective and expectation to list factors that are more evident as promoters of the deforestation process, Rodrigues (2004) exposed to consider the roads/highways as causes of deforestation, mainly, it is a mistake, which associatively Margulis (2003) emphasized that economic viability of ranching encouraged by the implementation of the road is who, synergistically promotes deforestation and deduct the sense of environmental sustainability in the region.

Looking through the eyes "point $x$ counterpoint", even in coexistence scenario "not harmonious", between degradation and sustainability in the Amazon region, given the urban complexities and everything inherent to implementing a sustainable economic development process, a brief overview

\footnotetext{
1 Apud Santos (2010). "The main drivers of deforestation in the Amazon (2002-2007) - an econometric and spatial analysis. University of Brasília - 2010. Master's Dissertation - CDS / UnB.

2 Idem.
} 
exposed to corroborate a hypothesis, not an argument, in common among the concepts presented, ie both have, subliminally, a purpose of environmental protection and / or socio-ecological to the biome, in respect to the characteristics and interventions that the process evolution of urban occupation translates.

Finally, reiterating Abramovay (2010), "What is at stake is human cooperation throughout this process" and the effort to link development to environmental variable and/or ecological, admitting that innovation conditions; redefinition of government actions (State's role); investment in research and technology and involvement of promoters of institutional initiatives effecting the monitoring demographic, spatial, environmental, climate and biodiversity in the Amazon region, based on the sustainability argument and growth and sustainable economic development. What to do so, Saporta (2009) argued that it is "... fundamental to Brazil think and plan the occupation and exploitation of the Amazon rainforest in order not to miss the great opportunity that this region provides for the contribution of economic development and social of the country."

Regarding the designs that enable the expansionary projects below the mesh structure of the Amazon transport, these researchers were identified as triggers of far-reaching consequences regarding forest destruction, since the thinning occurred for openings in buildings or pavements roads tend to condemn surrounding forest regions to these new roads (Ferreira et al., 2005; Soares-Filho et al 2004, 2005.), ie, paving, building and expanding roads are shown as the main determinant of future standards process Amazon deforestation.

Another pertinent question is not only the "incentive" to deforestation caused by the facility created the marketing of products removed from forests for the traditional, for example, but the question that this process generates an impulse to social conflicts and illicit activities. That is, to be effective, this type of development should not only verify the economic viability generated with the work, but also measure and identify the various side effects. ${ }^{3}$

3 See Fleck (2009). 
There should be tools to verify and ensure a more equitable distribution of benefits and losses of works like these. The vision should be directed in this regard to the cost-effective facing the social and environmental, within a purpose harmonizing / integrating actions.

According to Santos (2010), "... in the current decade the pace of deforestation has decreased, but the total deforested area of accumulated is large, on the order of 738000 square kilometers (since July 2009), equivalent to the devastation $14.70 \%$ of Amazon or $17.64 \%$ of the Amazon biome." From a statistical and econometric bias, studies indicate that the annual moving average of deforestation is $17,185.86 \mathrm{~km}^{2}$, which reflects an annual increase of the stock which is equal deforested to $0.34 \%$ in the Amazon and $0.41 \%$ in the Amazon, statistical analysis that brings together the period 1988-2009.

It should be noted that the scope of the process of deforestation in the Amazon is reflected in various forms of vegetation associated with the timber extraction process to the suppression of undergrowth fundamentally destroyed by heat sources (fire) in disturbed areas or not.

The latest discussions on the application of technologies or methodologies can reduce the process of deforestation and / or avoid it have been advanced in the academic and market space, in order to translate effective and efficient monitoring actions for this purpose, above all, as the implementation of road infrastructure in the Amazon region.

On admission the concept of avoided deforestation from the perspective of comparative-static analysis to understand what this is, according to the IPAM, there is the argument which avoided deforestation is defined by the reduction in the rate of deforestation of an area of so that the resulting rate of clearing is smaller than in a scenario without intervention to reduce the forest conversion process.

It should be emphasized that in the context of all deforestation in Amazonia or the Amazon, the search by precise indicators that are clearly responsible for the evolution or involution of deforestation or deforestation process in the Amazon region. 
In this perspective, Margulis $(2003)^{4}$ said that deforestation is due to the implementation of agricultural projects of a large scale. Prates (2008) argued that deforestation has several factors and is spatially uneven ${ }^{5}$.

Based on the analytical principle "point and counterpoint," it is understood that the deforestation dynamics and has had its aggravation from derivatives settlements of the urbanization process also reflected by the rural population.

In perspective and expectation to list factors that are the most obvious promoters of the deforestation process, Rodrigues (2004) emphasized that considering the roads / highways as causes of deforestation, mainly, it is a mistake, which associatively Margulis (2003) pointed out that the economic viability of ranching encouraged by the implementation of the road is who, synergistically promotes deforestation and deducts the sense of environmental sustainability in the region.

\section{FEATURES OF THE REGION AND STUDY AREA}

In various climatic representations and several existing biomes in Brazil, there is the world's forest - the Amazon Forest, which has more than 6 million square kilometers of untold riches.

The world's largest biodiversity belongs to the Amazon, whose climate is humid equatorial, housing approximately $20 \%$ of the species on the planet. It is understood that the base of the sustainability of the ecosystem is the source of natural resources and services used by humans, or biodiversity.

The Brundtland Report (1987) found that biodiversity conservation encompasses moral, ethical, cultural, aesthetic and scientific, requiring character responsibility actions intra-generational and intergenerational, assuming the "Fairness Principle.".".

\footnotetext{
4 Apud Santos (2010). "The main drivers of deforestation in the Amazon (2002-2007) - an econometric and spatial analysis. University of Brasília - 2010. Master's Dissertation - CDS / UnB.

${ }^{5}$ Idem.

6 See Beder (2000). The concept of equity (in the environmental bias) is embraced by the defense that scientific knowledge about the functions of natural ecosystems and the possible consequences of their degradation and depletion is, at best, uncertain. The depletion of natural capital can lead to irreversible loss of species and habitats, which can not be recreated using capital of human origin.
} 
The Amazon biome region where is located the study area (Figure 1), presents different characteristics in connection with existing micro-climates distinct, which causes changes in the urban dynamic in the relations of production (supply of goods and services, employment and unemployment), the urban-road structure and accessibility to the population (because of specific local transport modal operations), among others.

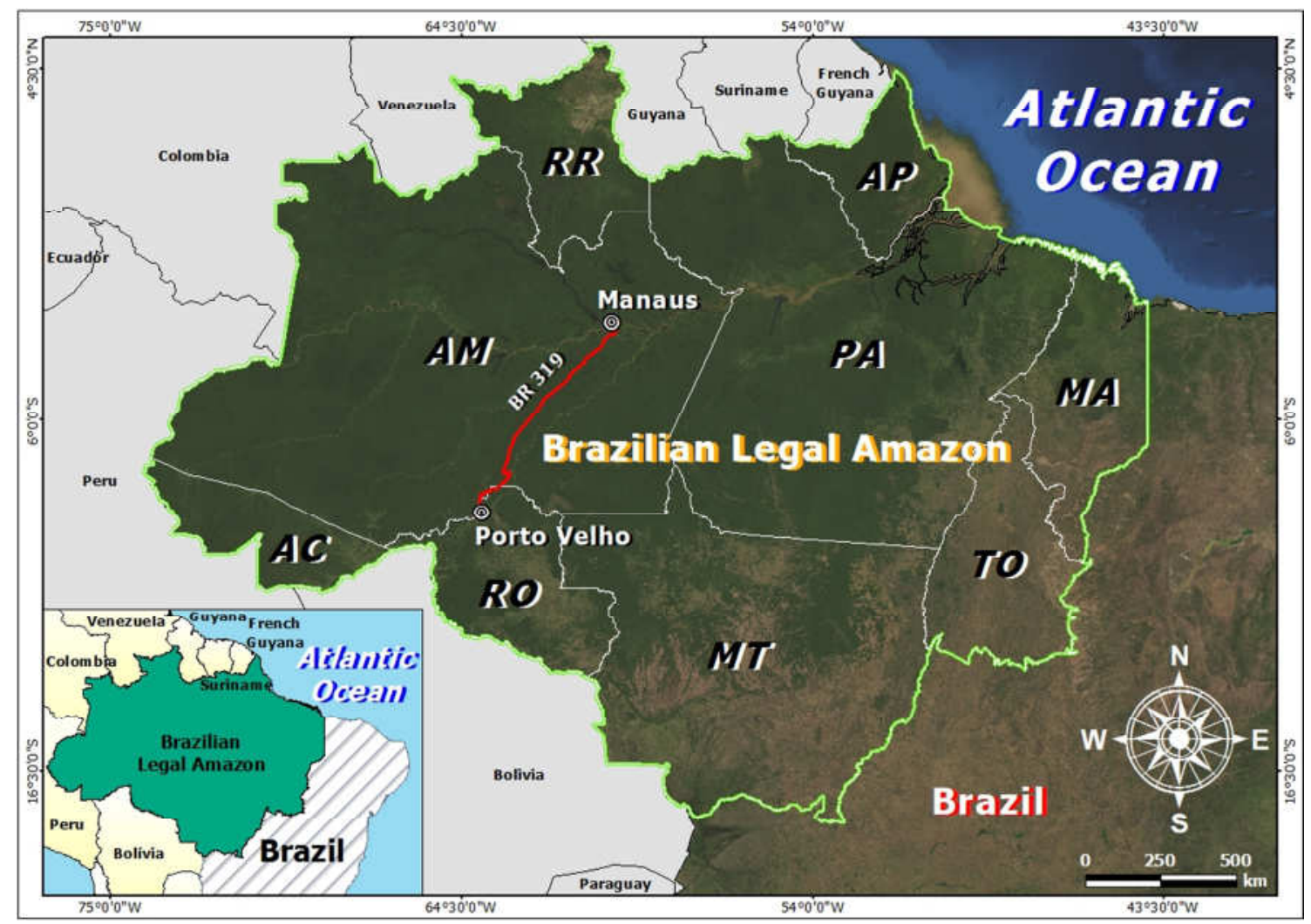

Figure 1. Regional geographical framework of the Amazon and the BR-319.

According to technological advances how to map areas and identification of species (fauna and flora), this biome conforms, in itself, a collection of information, data on the local soil, information directed to the lakeside complex (limnology aspects and watersheds), and the climate vulnerability in which it is placed, because of the above elements and disparate structural economic scenarios.

The highlight for the intersection between the states that comprise the route of the BR-319 highway (Amazonas and Rondônia, as shown in Figure 4) reiterates the analysis of aspects of population differentiation, that is, the form of 
occupation of the region, which sees the different economic and environmental status of the capital Manaus (AM) and Porto Velho (RO).

The BR-319 highway crosses the municipalities of Canutama, Humaitá, Tapauá, Manicoré, Beruri, Borba, Manaquiri, Careiro, Careiro da Várzea and Manaus, possessing over that stretch a variation in trafficability conditions. Excerpts in Careiro da Várzea and Careirosituated on the banks of the Amazon river and Tupanã respectively have vehicles flows with a certain trafficability (about $165 \mathrm{~km}$ ), but stretches that connect the AM-356 to Humaitá (about 500 $\mathrm{km}$ ) They are impassable due to little or even no road infrastructure, bridges and shoulders. From this section onwards (in Humaitá, trunking height with the Trans-Amazon highway, until the arrival in Porto Velho) there is fully capable of trafficability, standing in his fairly paved majority (Árbocz et al., 2005; DNIT, 2008).

According to Fearnside (1997), the process of rebuilding BR-319 stretches down the only road link between the Amazon and the Central-South of the country, that is, seeking to facilitate dialogue between the capital Manaus and Porto Velho. In its history, the highway was opened by the Army in 1973, and at present only passable close these capitals, which means that its central portion is abandoned since 1986.

One of the main justifications for the rehabilitation of just over $885 \mathrm{~km}$ extension of the Manaus-Porto Velho highway (BR-319), with the paving of approximately $400 \mathrm{~km}$, is to promote the transport of loads of free zone of Manaus toward South-East region of the country, optimizing then the flow of timber and non-timber one of the main consumers of the products resulting from this region. Another understanding of the case of the BR-319 highway is that in addition to these two activities, this work includes the construction of four new bridges between Manaus and Porto Velho, these buildings which help to promote local integration.

The resumption of construction activities (reconstruction and paving) started in 2009 and had a completion scheduled for 2012 and 2018 of a stretch to another stretch.

According to Fearnside and Garcia (2009), the paving of BR-319 has great public appeal in Manaus, largely from the state and national political environment. 
Work on the Manaus-Porto Velho began in 2005 but due to a deficiency in the compliance with environmental requirements of Article 225, §1, IV of the Federal Constitution (CF/88), the lack of environmental impact studies and, consequently, not to issue the environmental Impact report (EIA-RIMA), important tools for the implementation and evaluation of the principles of sustainable development and prevention of potential impacts, all works were halted, actually caused due to the environmental agency consider road to recovery as a new project. le non-compliance with the requirements requested by the environmental agency raised questions on the road revitalization process for the stretch considered.

However, agreements between local stakeholders resulted in the preparation of an environmental study of the middle stretch of the route between kilometers 250 and 655.7, where UFAM - Federal University of Amazonas - was the entity responsible for preparing the study, delivered in 2009 , where the preparation of the EIA/RIMA resulted in more than 1,000 pages of observations, and preliminary diagnostic evaluations on the feasibility of completing the project in view of the purpose of avoiding or at least offset the environmental problems of the work, whose technical, scientific analysis, social and economic have been made by a multidisciplinary team.

\section{METODOLOGY}

With regard to methodology, this article is based on literature that deals with the issue of deforestation in the Amazon and especially the design of avoided deforestation in the reconstruction process of the BR-319 highway. Therefore, the study was divided into three basic steps:

1. Literature review inherent in the theme and the Amazon region and characterization of the study area from field research (research process on the BR-319 highway, its history and its reconstruction process);

2. Deforestation percentage identification in the BR-319 region, from the IBGE and PRODES / INPE, with data analysis and information about the status of deforestation in this study area (brief history of rodoviarismo in the northern region; the publications relating to the environmental management of highways, associated with economic bias, risk and environmental cost); and 
3. Determination, from a quantitative analysis, the percentage avoided deforestation identified in the BR-319 highway reconstruction process, considering data on highway route of the images in the 2009-2010 period and quantitative results of this process (for the purpose of compose a scene on the environmental management process of this highway, admitting the results obtained by the implementation of environmental programs).

\section{RESULTS}

The main results of the research are qualitative, from the point of view of analysis based on avoided deforestation in the BR-319 highway as well as the evolution and / or regression of deforestation in the reconstruction process of the BR-319 highway.

\section{AVOIDED DEFORESTATION: CONCEPT AND APPLICATION ON HIGHWAY BR-319}

Avoided deforestation is conceptually defined by the result in reduction of deforested area, and determined by a deforestation rate compared between two different moments and considering an area undertaken by human intervention. Quantitatively, this concept is expressed as a linear equation as follows.

\section{$[$ Tdt2/Tdt1] $\vee$ TDe $<0$}

equation (1)

The concept of avoided deforestation from the perspective of comparative static analysis assuming, in order to understand what this is, IPAM believes that where the avoided deforestation is defined by reducing the rate of deforestation of an area, the resulting deforestation rate will be lower than in a scenario without intervention in order to reduce the forest conversion process.

It should be emphasized that in the context of all deforestation in the Amazon, the search by precise indicators that are clearly responsible for the evolution or involution of deforestation or deforestation process in the Amazon region is not limited in this study, which proposes guidelines of its development.

At first glance, it is understood that the practice of avoided deforestation causes less carbon emissions into the atmosphere, since the maintenance of trees in their natural condition and its unspoilt functions leads indirectly to a 
reduction of the increase in pollution levels atmospheric, inferring this way, in no contribution to global warming.

The interest for the restoration of traffic on this highway was based on the main purpose of connecting Manaus to the southeast of the country through a road extension, which is a theoretically slow pathway, but with relatively low costs, as noted Teixeira (2007). Other contact options between the capital cities of this region are characterized by airway, river-sea (cabotage) and road and river. Other interests associated with the "fruits" of the revitalization of the BR319 are presented by Amazonas state, which aim to different connections from projects of road extensions or secondary roads that would connect the municipalities located on the banks of the Purus and Madeira River(Fearnside et al., 2005).

Diverse questions have been generated by professional research institutions, NGOs and universities as the environmental and economic feasibility for the implementation of this work. An important question refers to speech that paving the road will smooth the way to deforestation, land grabbing, land conflicts and social problems in one area which is currently regarded as the most preserved and unspoiled the Amazon biome, which would compromise much biodiversity of the region, contributing to alarming scales in relation to global warming.

The major concern is occurring in this region a devastating predatory process over land occupation, driven by the highway restoration. In this sense, Fearnside (2005) and Reid \& Souza (2005) demonstrated the developments triggered elsewhere in the North from such aspects. Because of the fragility and institutional susceptibility of this region, the LBA - Large Scale BiosphereAtmosphere Program in the Amazon, under the Ministry of Science and Technology, reported that only the recovery of the highway advertising would have caused the increase in land grabbing actions and occupation of land in the vicinity of the highway, the process also occurred with the BR-163, as observed Alencar et al. (2005).

An important action of the Federal and State Governments to contain these advances, damaging the local environment, was the implementation of UC's - protected areas - around the highway. These, also called ALAP - Area about Provisional Administrative Limitation - represent a mosaic of protected 
areas in the BR-319 region and cover an area of 15.4 million hectares, of which over 5 million converted into FLONAS (National Forests), focusing mainly on timber production. This type of measure is shown as extraordinary to contain the advance of deforestation in the region. From such actions, there was a public consultation process on the proposals for the creation and expansion of several CUs in the highway's area of influence (ICMBIO et al., 2008).

Following this perspective, it is known that avoided deforestation under this venture would lead to carbon emissions into the atmosphere, then, this work has also been shown, in a sustainable perception, possible impacts to this region of the Amazon biome, if not incorporated into practice avoided deforestation.

Considering deforestation and its consequences, according Moutinho et al. (2001) in quantitative terms in relation to the production of carbon, the Amazon forest stores an equivalent amount that all people in the world issue for over ten years. So, if the expectation of deforestation rate is confirmed, the amount of carbon emitted in the void region almost half of the emission reductions that are expected if the Kyoto Protocol were implemented with full success.

Among the many studies on this topic, Saatchi et al. (2007), Soares-Filho et al. (2006) and Fearnside et al. (1997) determined that the biomass and carbon stocks in the Amazon biome ranges from 60 to 200 tons of carbon per hectare stored in the form of live biomass in the various types of native vegetation in the Amazon region. This would therefore be a quantitative data that demonstrates the representation that the practice of avoided deforestation could mitigate emissions of gases contributing to the greenhouse effect. In order to agree on the values, the Brazilian Government, the Amazon Fund and the Ministry of Environment adopt 100 tons of carbon per hectare as average.

Another factor of great importance in view of Huntingford et al. (2004) and Jones et al. (2005), it is that the advance of the Amazon forest degradation and death contribute a significant feedback to enhance the greenhouse effect, since the release of stored carbon happen both out of forest biomass and liberation from the ground. Added to this the Brazilian deforestation is today $75 \%$ of the country's $\mathrm{CO}_{2}$ emissions (Houghton et al., 2000), thus indicating a significant contribution to this development problem at hand. 
Young (2008) studies indicated that the trend for the payment for environmental services in the Amazon appears as a possibility to change this situation, showing how a strong financial mechanism to encourage the reduction of potential actions that generate carbon into the atmosphere, mainly deforestation. Thus, this would be a methodology reduced and cost effective to curb deforestation in the agricultural frontier in the state of Amazonas. Admitting that it is combined with the implementation of projects for expansion of protected areas, the development of environmental management capacity would be significant both as protected areas on private land.

The components that meet the mobilization for the implementation and development of the Highway Reconstruction Project BR-319 - Manaus (AM) segment - Porto Velho (RO) - are admitted from the actions of the Brazilian State in socio-economic and environmentally sustainable development of the region Amazon and especially the evolution of the tangents regional characteristics to the stretch comprising the project execution.

Admitting that one of these components is tripartism of the relationship between state, civil society and research institutions, is established to shed middle of planning the long term, it enters local realities, social participation and environmental management.

According to the predecessors discussions to the initial implementation of the project, that is, in its design and implementation, the need was that, given the state intervention in establishing a scenario with strong environmental governance, to consolidate not only the object of this section licensing, but it was included the entire state of Amazonas. In this context, consider that the development of the works on the BR-319 highway using modern engineering techniques and the implementation of measures and proposed environmental programs, the core of sustainable development assumes the respect for the environment and people's quality of life, a fact reiterated by the Environmental Impact Assessment - EIA / RIMA, which completed the environmental feasibility of the project.

According to the conclusions of the Environmental Impact Assessment of Highway BR-319, produced by UFAM - Federal University of Amazonas, it was ratified the relevance of this work as an instrument of integration of the states of Amazonas and Rondônia to the rest of the country and the importance of she 
was executed based on economic foundations, strong and balanced social and ecological. It is noteworthy that the central proposal of the highway, according to the same study, is to serve as infrastructure for the integration of Central Amazon with the rest of the country, therefore, the implementation of road should be the guiding element of actions in order to avoid occurrence of damage to environmental processes, particularly those related to bone fish phenomenon, when a system of roads with various extensions binds to a main road.

The possibility of occurrence of these processes should not be discarded in highway management procedures, especially after his recovery. The increase in deforestation rates can, in scenarios modeled from the reality observed in the southern and western portions of the Amazon to jeopardize the Amazon ecosystem in a few decades and should be avoided at all costs. Allow the process of opening and use of the highway just as has happened, either for lack of appropriate action or failure to ensure the success of these may be increasing factor in deforestation rates in the Amazon. Thus, planning and environmental management of activities related to the reconstruction of Highway BR-319 are the result of DNIT actions of conjugation and institutions / collaborating entities, implementation and implementation of environmental programs run, matching and sharing challenges and successes in the transcurrent project. The dynamic management of data and information, where the subsequent transfer of the same will be done through on-site monitoring of environmental programs in its stages of implementation and execution, it proposes reflect an ongoing process of oversight, supervision and monitoring under the bias of mitigating actions and compensatory associated with the object of programs and the identification of avoided deforestation practices.

In a context of territorial analysis, the southern state of Amazonas, where is the BR-319, has large and growing pressures from external means and internal biome. This area has been shown as concentrating most recent deforestation throughout the state.

The occurrence of unofficial roads is a reality in large expanse of surrounding the region driven by the highway work. This is evidenced as the major vehicle for change of scenery and the advancement of reversing the conditions of the current scenario. Another point alerted by Fleck (op. Cit) is that 
new deforestation runners tend to intersect, causing major changes in forest cover, especially in the vicinity of Manaus and axes that radiate toward the Rondônia, Roraima and off AmazonasRiver.

The implementation of environmental programs while syndicated action of the BR-319 highway reconstruction process combines efforts of conservationist sense and / or environmental conservative, when stocks stumble in the area of influence in the area under provisional administrative limitation (ALAP), where it was found advances deforestation, increasing estimate of approximately $33 \%$, representing around 5.1 million $\mathrm{m}^{2}$.

Thus, with the same object of action, institutions with large national and international recognition (Friends of the Earth-Brazilian Amazon, Amazon Vitória Foundation, Greenpeace, Environmental Institute and WWF - Brazil) effected interfaces with representatives of the federal and state governments, demonstrating that one of the potential solutions to curb deforestation throughout the area of influence of the BR-319 is through the establishment of protected areas, action that induce, mainly due to the presence of FLONAS National Forests, the development of exploratory activity of wood, triggering a strong demand for generating socio-environmental conflicts.

Such circumstances may be associated with the implementation of the Green Free Trade Zone Program, established by the government of Amazonas, which develops, gradually, the sustainability of logging in the Amazon, so as not to provide a disorderly growth of the activity, a fact driven by ALAP.

\section{EVOLUTION AND/OR DEFORESTATION INVOLUTION IN HIGHWAY RECONSTRUCTION PROCESS BR-319}

"Roads leverage - seldom create - economic and social change. This assertion needs to be adjusted to contemplate contemporary concerns of humanity. Roads cause deforestation or roads accelerate deforestation; they give rise to the process of biodiversity destruction or amplify a process which has already started at a particular point of geographic space? (...) One of these issues is undoubtedly related to the economic costs (and therefore social and environmental) and economic benefits (and, again, social and environmental) building infrastructure for different modes transport." (Nogueira, 2009). 
There is no doubt about the purpose of a transport infrastructure project, especially road, that the desired breakthrough for the implementation of a $\mathrm{road} / \mathrm{highway}$ is to promote local development.

The stimulus to economic development brought by a road infrastructure project becomes evident when the benefits are identified and noticed while a dynamic element (evolution) in the region.

The characterization of the above developments, it is also cite an analogous case to the BR-319 highway (Manaus -Porto Velhostretch), vis-à-vis the complexity in which they are involved, because it has similarities, and this case the process of revitalization of BR-163 (Cuiabá - Santarémstretch), the safeguarding of the right proportions, because it proposes a dynamic growth and local economic development, has assumed the environmental variable in all the actions that have defined as benefits of generating agents to the use of road transport, the regional integration process and the cost-effectiveness of the whole process of paving / reconstruction of roads.

In the case of BR-319 highway and other federal highways, the conjunction of efforts to print strong effect of monitoring the implementation of the licensing process and environmental programs through a partnership between the Ministry of Transport and the Ministry of Defence, jointly with the Army Brazilian produced another tool to support environmental management of federal highways.

Creating a Support System Road Environmental Management Federal (SAGARF) presenting data and information systematized by CENTRAN (Center of Excellence in Transportation Engineering) provided another breakthrough in the accompanying proposed actions on road projects, which put, until then, the environmental licensing as an element fundamentally beacon of actions aimed at the environmental management of highways.

Another condition that emphasizes the technical and technological advancement in the case of BR-319 highway and which served to identify benefits that the road reconstruction would bring to the region was the use of the RED software (Roads Economic Decision Model), mainly for economic evaluation highway projects, with a specific module to estimate local benefits the HDM-4 (Highway Development and Management System) in order to be 
able to generate a technical result, as a parameter able to lead to an unbiased evaluation.

So in agreement that there are measurement instruments and Environmental Programs - Compensatory Planting programs and recovery of degraded areas, the application of these is critical to the understanding of a process that is rooted in the dichotomy developing $x$ sustainability because other variables, between them the level of traffic, the road surface quality and the analysis of proportions similar highways are used as an evaluation object to the composition of a breakthrough scenario from the model adopted by the World Bank for this purpose.

Because of developments in road transportation in Brazil, an advance that deserves to be exposed is the proposal of the Brazilian government to implement the Ecological Economic Zoning Program (EEZ), which admits subsidize social planning decisions, economic and environmental development and use the national territory, based on the concept of sustainability.

Within all this context it becomes important to make a comparative analysis at the international level in the context of Latin America, in order to verify how Brazil is located at the interface with other countries, especially with regard to environmental performance analysis of road projects.

Reiterating the World Bank involvement in environmental issues and road environmental management, the Department of Environmental y Desarrollo Sostenible Socially participate in a forum of discussions by SLUAT - Sociedad Latinoamericana de Ambientales Transport Units, an institution that publishes works related to road and environmental management that created the information collection, laws and guidelines directed to the theme Transport and the Environment, which Brazil has a measured participation with the Santa Catarina DER unit.

Among the nuances surrounding a project to establish a modal transport, such as the highway object of this study, we reiterate the argument which gave Rocha (2006):

"... Many are the interests involving the construction of a highway, thus diversifying the scenario of the actors involved in this process for the design and construction of a highway the joint is necessary contemplating from its demand 
on the part of groups that will benefit from the construction or improvement, through complex social and political articulation that exists."

By this argument, the highlight advances give rise to setbacks resulting from the reconstruction of the BR-319 highway. On the other hand, it is essential, in Brazil, giving relevance to changing the governance scope to which infrastructure projects are linked.

In order to rate reversals, we have:

- Lack of spatial planning within the Brazilian Amazon;

- Deficiencies in land management in case of BR-319 highway and other federal roads;

- Management of the highway margins;

- The need for a road land management;

- Integrated management of public institutions on the project;

- Unchanged the interpretation that the environmental education process is finite;

- Negative Impacts on local urban areas (bordering municipalities with highway);

- Expansion of logging;

- Environmental liabilities associated with the highway changes.

Thus, as many as were setbacks would be added, but not up to this study define them, but cite them and present them for discussion as they involve the case of BR-319 highway.

In this way, the relationship forward $x$ rewind the environmental management of highways and especially in the reconstruction process of the BR-319, brings to the region positive and negative elements which are reflected in local urban scenario, in that the municipalities which runs through the highway begin to develop urban infrastructure, including: implementation of transmission lines for electricity distribution; footprint outside and within the highway right of way, that is, new occupations and change of land use (20092010); expansion of assistance from the National Institute of Colonization and Agrarian Reform (INCRA) to land allotments; principle of real estate speculation, which will lead to the formation of an environmental liability in the 
future, although nowadays materialize the restructuring of a region with economic development needs.

It is true the condition that conflicts while negative aspect of this process, are inherent in the new condition in some members of the BR-319 municipalities in the relevant section. However, as they occur, the dynamics of occupation and diversification of socioeconomic and environmental activities start to present a format that would fit the state's participation to curb, for example, the illegal occupation along the highway, from the aspect of illegality and determine - by legal instrument - the establishment on the highway, mainly in relevant sections of roads or park Ecovias (green road), as a measure to advance the case for reconstruction and effective use of this highway.

Finally ratifies the observation that Brazil, in the last 45 years, underwent several times of "boom and bust" in the infrastructure segment, whether as a result of public management misconceptions or 'contagion' of an economically process troubled and depressed, which undoubtedly gave rise to the current scenario in the country's transport sector, especially road transport modal object region this study.

\section{CONCLUSIONS}

There is a claim that the Manaus and Porto Velho capital, by the biome which are components or representing the Brazilian geography, will acquire stronger importance from the point of view of government actions, especially regarding the implementation of conservative measures and ecologicalenvironmental preservationists for the biome and all its complex ecosystem and biodiversity structure.

It should be emphasized that permeate the discussion of biomes, and contumacious, the Amazon biome, fundamental questions about conservation, urban accessibility, growth of cities, development and / or regression of the local demographics, the endemic problem of poverty in the Amazon region, modal transport for the region (suitability) and, above all, deforestation, the latter with denotative growth on a large scale, as highlighted Fearnside (2009) Capobianco (2006) and Becker (2005). Considering the provision of these biomes, that is, its spatiality in Brazil, it is understood that they, from the 
viewpoint of environmental economics, make up the natural resources of the country as an asset ${ }^{7}$.

In this sense, the presentation of the spatial arrangement of Brazilian biomes (Figure 2) as elements that tangent the subject of discussion addressed promptly reveals the dimensions which the Amazon biome, compared to other, different and consolidates a degree of environmental concern / ecological widespread in academic and technical forums at the national and international scene as well as the ecological and environmental reality patent in light of potential human interventions and national economic dynamics.

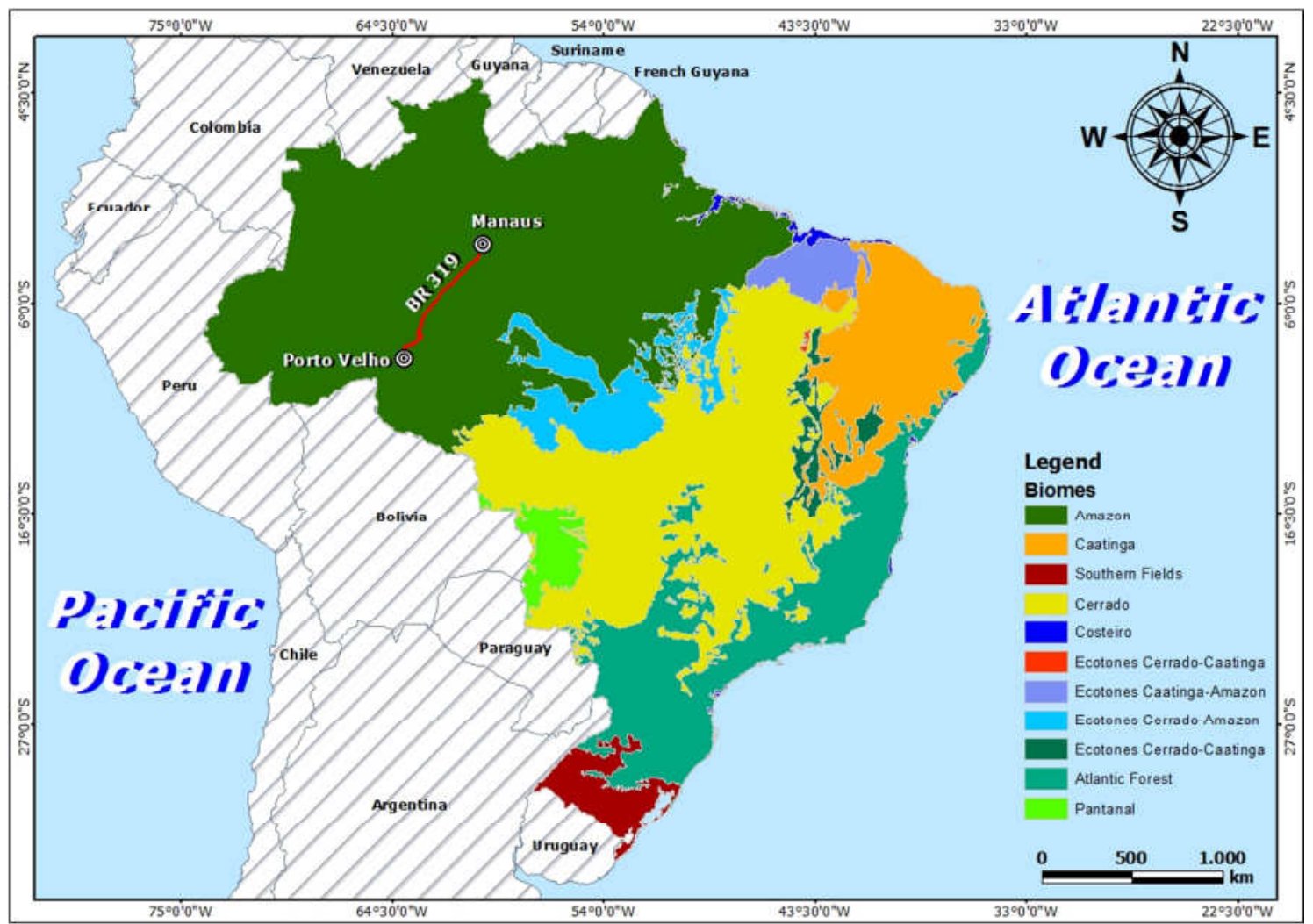

Figure 2. Spatial distribution of biomes and location of the BR-319.

In taking conceptual strand that comprises the Amazon biome as vital for synergies and climate vulnerability of the region and surrounding areas as well as the fact that this is the target of speculative actions on its natural heritage, especially in the Amazon Floreta, given their magnitude, which "The influence of the Amazon rainforest in the hydrological cycle transcends the boundaries of the region (...), because of its high rate of evapotranspiration and maintains high

\footnotetext{
7 It is a basic term used to express the set of goods, values, credits, law and resembled how the equity.
} 
atmospheric humidity in the region. This precipitable water in the Amazon atmosphere is transferred to other regions through low altitude jet streams (...). Thus the Amazon forest plays an important role in local climate and other regions, affecting the primary productivity of various ecosystems, agricultural productivity, hydroelectric power generation and even other biological processes such as the spread of diseases and zoonoses". (INPE, 2008).

The demonstration that, in the period studied (2009-2010, with consequences in 2011), shares about the process of deforestation in the Brazilian Amazon had real growth, in fact, has truth to it. However, the literature shows a process of deforestation with different backgrounds, such as increasing agropastoral dynamics; the advancement of livestock production area; the growth of the timber industry; the disorderly occupation of dwellings and how the spatial analysis is performed in the northern region of the country, with this scenario being compounded because of poor local governance policy; deforestation caused by the inclusion of road transport modes, among others.

Similarly, in the course of literature and field research for the implementation of this work, the concepts of environmental management and management intertwined, and the understanding of deforestation. However, the methodological approach provided a greater understanding of how to meet the proposed objectives, among them, identify the potential for avoided deforestation, applied as a sustainability mechanism, depending on the BR-319 highway restructuring in the Amazon biome.

From the avoided deforestation concept, assumed in work discussion, the characterization of the BR-319 highway, their deforestation history because of its deployment in the 1970s (precisely 1973), clarified the technical view (empirical) that allowed identify technical analysis of misconceptions about an established process of deforestation, which, by the reconstruction of the object of 877.5 kilometers (excerpt excerpt) road, has become an icon which went from a developmental scenario in the 70 s for a frame environmental devastation today.

The main question in the research was to identify core under a quantitative bias, role-deforestation kick of "good practice" in environmental management that highway projects in Brazil (and the world, from the late 1990s) adopted. So, considering that the regulatory framework for highway projects absorbed the 
environmental variable as a premise for promoting a roadside environmental management model, ceased the difficulty of finding similar cases in Brazilian federal highways, to outline answers.

The characterization of the study area, the identification maps, access and interpretation of satellite images to understand the variation of the deforestation process by tracing the BR-319 highway were elements that made up the entire line evaluation and analysis of this study.

The data and information generated in the technical reports from management and environmental supervision team DNIT-DF and IVIG-CETS (UFRJ) were also reviewed, on the basis of these documents contain the results of the environmental programs which effectively contributed to the consolidation of avoided deforestation concept as the results of the Domain Range Monitoring Program - PROFAIXA, the Area Recovery program Degraded - PRAD, the Program of compensatory Planting - PPC and, above all, the implementation process of these as something technically new in transportation engineering and essentially appropriate engineering / environmental management, added to proposing the environmental Management research line, area of concentration Sustainable Development Master's program in environmental UFRJ Polytechnic School of Engineering.

In analyzing the reports and data linked to the object of study, a methodology was admitted in which you can identify, through field visits, that the concept of avoided deforestation becomes feasible when faced with deforestation rates in the region, visa the data collected in the field, environmental Programs reports sent to the DNIT, which presented technical analysis on the environmental impact on the deforestation in the region, which is considered a minimum, and in some cases, of little relevance for the whole process of deforestation throughout the Amazon biome area.

The identification of the direct impacts of the highway reconstruction process is placed, technically, as a linear impact and collaborating not effectively throughout the process triggered by the impact of deforestation. However, it could be concluded, given the reviews and the features that the Environmental Impact Study that the indirect impacts, ie, the future impacts with some degree of local synergy, may be added to the context of deforestation in the Amazon region (biome Amazon) more expressive way. 
After identifying indicators for the interpretation of the deforestation process and thereby make an interface with the use of avoided deforestation mechanisms used in the highway reconstruction, the quantitative analysis defined by equation Chamber \& Young (2007) shows that the rate of deforestation in the Brazilian Amazon reduced. In addition, the 2009-2011 period shows that this contrast can be referenced to the Domain Range Monitoring Programs in the highway reconstruction process, making reiterate that deforestation minimization practices do not raise deforestation actions to the whole Forest, the biome or the Amazon region.

Another conclusive discussion of this study is that the Environmental Management of the highway had strong supervision of the governing body DNIT, depending on the governance policy that recomposed the government's actions to the issue and the environmental management of highways in Brazil.

So without any allusions to the Growth Acceleration Program, however, understanding that it is the driving force of investment in transport modal infrastructure in Brazil, for the moment it is necessary to mention that the federal highways, including BR -163, BR-101 and BR-158 NE, and obviously the BR-319, were and are targets of a group of the Ministry of Transport shares to effect the concept of sustainable highways, having as parameter the discussions dealt with in forums international and especially Latin America.

It is also possible to conclude that the environmental costs and the economic costs of deforestation, originating in the reconstruction of BR-319 highway, have veracity of information and contributed to the analysis and understanding of the shaft issues which supported this work. However, admit a chaotic bias for without governance process of deforestation, which is essentially antagonistic to the current governance policy of the Brazilian government has placed since 2008, especially in the figure of DNIT by CGMAB (General Coordination Environment), as determined by the Ministry of Transport and in association with the Ministry of Environment.

In this way, an environmental management process in roads, depending on the complexity of the BR-319 case, mainly due to biome which cuts state action towards the dynamics of environmental management on highways and in accordance with the general scope of the project reconstruction of this highway, identifies agents/actors responsible for managing the process, in order to 
minimize environmental risks through the use of efficient management methodologies, to meet the effect supervisor and inspector of the competent bodies.

There is the argument that the legal compliance and the adoption of a tacit preservationist sense in the manager process were necessary for the composition of paving projects/reconstruction of federal highways. So, from the standpoint of how exposed is the government's disability case does not meet this purpose, it would define its management failure for this purpose.

The existence of social character of appeals, ecological, environmental, marketing, corporate and government made it taken a careful look at the case of the BR-319 highway, which occupies both the biome as the "development project" that symbolizes. However, promote the management of highways with foundations in environmental management, the use of feasible mechanisms that determine the reduction of area deforested and that signal to reduce costs to enable growth and economic development project is the contribution that this work wants to present.

Finally, the proposal to generate a diagnosis of a concentrated tamanhamente process from the perspective technical and diffuse the academic point of view, there is a feedback relationship of these two aspects, which provides generating research highlighting the need to not steal the Academy on discussion of methods, forms and analyzes that are contributory to a subject of discussion which broadens not only the reasoned debate on transport engineering techniques and the environment, most also promotes the identification of causes, reasons and ways to generate joint solutions to natural scenery and/or caused by human action, which guide the development of an integrated setting and with better conditions for the coexistence of technologies (technical/mechanisms), social and environmental demands and sustainability.

\section{REFERENCES}

Abramovay, R. (2010). Desenvolvimento sustentável: qual estratégia para o Brasil? Revista NOVOS ESTUDOS CEBRAP, n.87, julho 2010. pp. 97-113 Ahmed, A.S., Billings, B.K., Morton, R.M. \& Stanford-Harris, M. (2002). The role of accounting conservatism in mitigating bondholder-shareholder conflicts over 
dividend policy and in reducing debt costs. The Accounting Review, 77(4), 867890.

Alencar, A., Micol, L., Reid, J., Amend, M., Oliveira, M., Zeidemann, V., \& de Sousa, W. C. (2005). A pavimentação da BR-163 e os desafios à sustentabilidade: uma análise econômica, social e ambiental. Instituto Centro de Vida (ICV), Cuiabá, Mato Grosso, Brasil.

Árbocz, G., Naliato, V. \&Reinecke,W.(2005). Relatório de vistoria técnica. Empreendimento: rodovia BR-319, entre as cidades de Porto Velho, no Estado de Rondônia, e Manaus, no Estado do Amazonas, sob responsabilidade do DNIT. Departamento Nacional de Infra-estrutura de Transportes. COAIR/CGLIC/DILIQ/IBAMA, Brasília, DF. 80 p.

Arima, E., Barreto, P., \& Brito, M. (2005). Pecuária na Amazônia: tendências e implicações para a conservação ambiental. Instituto do Homem e Meio Ambiente da Amazônia-IMAZON.

Becker, B. K. (2005). Geopolítica da amazônia. Estudos avançados, 19(53), 7186.

Beder, Sharon. (2000) 'Costing the Earth: Equity, Sustainable Development and EnvironmentalEconomics', New Zealand Journal of Environmental Law, 4, pp 227-243.

Brundtland, G. H. (1987). Report of the World Commission on environment and development:" our common future.". United Nations.

DNIT. (2008). Condições das rodovias. Estado: Amazonas / BR-319. Disponível em:

[http://www1.dnit.gov.br/rodovias/condicoes/condicoesdrf.asp?BR=319\&Estado $=$ Amazonas\&drf $=1]$.

Fearnside, P.M. Serviços ambientais como estratégia para o desenvolvimento sustentável na Amazônia rural. In: C. Cavalcanti (ed.) Meio Ambiente, Desenvolvimento Sustentável e Políticas Públicas. São Paulo, SP: Editora Cortez, p. 314-344, 1997.

Fearnside, P. (2005). Deforestation in Brazilian Amazonia: History, Rates and Consequences.Conservation Biology 19(3): 680-688.

Fearnside, P.M., \& de Alencastro Graça, P.M.L. (2009). BR-319: A rodovia Manaus-Porto Velho e o impacto potencial de conectar 0 arco de desmatamento à Amazônia central. Novos Cadernos NAEA, 12(1). 
Fleck, L. C. (2009). Eficiência econômica, riscos e custos ambientais da reconstrução da rodoviaBR-319 In:Conservation Strategy Fund (ed.) Conservação Estratégica (17). p. 46-68.

Houghton, R.A., Skole, D.L., Nobre, C.A., Hackler, J.L., Lawrence, K.T., \& Chomentowski, W.H. (2000). Annual fluxes of carbon from deforestation and regrowth in the Brazilian Amazon. Nature, 403(6767), 301-304.

Huntingford, C., Harris, P.P., Gedney, N., Cox, P.M., Betts, R.A., Marengo, J.A., \& Gash, J.H.C. (2004). Using a GCM analogue model to investigate the potential for Amazonian forest dieback. Theoretical and Applied Climatology, 78(1-3), 177-185.

IBGE - Instituto Brasileiro de Geografia e Estatística. 2004. Disponível emhttp://www.ibge.gov.br/home/presidencia/noticias/21052004biomashtml.shtm IBGE - Instituto Brasileiro de Geografia e Estatística. 2004. Disponível em http://www.ibge.gov.br/home/estatistica/populacao/censo2000/

IBGE - Instituto Brasileiro de Geografia e Estatística. 2015. Disponível em http://www.ibge.gov.br/home/geociencias/geografia/mapas doc5.shtm.

ICMBIO, SDS/AM, SEDAM/RO \& CSF. (2008).Grupo de Trabalho BR-319 (Portaria N. 295 . MMA,de 22.09.2008). Subgrupo: Proteção e Implementação das Unidades de Conservação da BR-319. Resumo Executivo. Manaus-Porto Velho. $27 \mathrm{p}$.

INPE - Instituto Nacional de Pesquisas Espaciais. Dados sobre desmatamento na Amazônia.Disponível em: http://www.obt.inpe.br/prodes/index.html.

Jones, C., McConnell, C., Coleman, K., Cox, P., Falloon, P., Jenkinson, D., \& Powlson, D. (2005). Global climate change and soil carbon stocks; predictions from two contrasting models for the turnover of organic carbon in soil. Global Change Biology, 11(1), 154-166.

Margulis, S. (2003). Causas do desmatamento da Amazônia brasileira.Banco Mundial, Brasília.Vol. 1: 11-17, 2003.

Moutinho, P., Nepstad, D., Santilli, M., Carvalho, G., Batista, Y. Asoportunidades para a Amazônia com a redução das emissões de gases do efeito estufa, Brasília,

2001.

Reid, J. \&Sousa Jr.,W. (2005). Infrastructure and conservation policy in Brazil.Conservation Biology, v.19, n. 3, pp. 740-746. 
Reid, J.W. and Bowles, I.A. 1997. Reducing the impacts of roads on tropical forests. Environment, v. 39, n. 8, p. 10-15.

Rocha, A.P. (2006). Uma Análise da Integração em Rede: Os Transportes Aéreos no Estado da Bahia. Dissertação de Mestrado. Instituto de Geociências. Universidade Federal da Bahia.

Saatchi, S. S., Houghton, R. A., Dos Santos Alvala, R. C., Soares, J. V., \& Yu, Y. (2007). Distribution of aboveground live biomass in the Amazon basin. Global Change Biology, 13(4), 816-837.

Soares Filho, B.; Alencar, A.; Nepstad, D.; Cerqueira, G. C.; Vera Diaz, M.; Rivero, S.; Solórzano, L. andVoll, E. 2004. "Simulating the Response of LandCover Changes to Road Paving and Governance Along a Major Amazon Highway: The Santarém-Cuiabá Corridor". Global Change Biology, vol. 10, n. 7, pp. 745-764.

\section{Acknowledgments}

The authors thank the Environmental Engineering Program, the Polytechnic School of the Federal University of Rio de Janeiro, as well as the contributions of the editor and reviewers.

Recebido: 25/05/2015

Aprovado: 26/06/2014 